Author's accepted manuscript: Submitted to Urban Studies

\title{
Shaping urban consolidation debates: Social representations in Brisbane newspaper media
}

Katrina Raynor, Tony Matthews, Severine Mayere

Please cite as:

Raynor, K. Matthews, T. \& Mayere, S. (2017) Shaping urban consolidation debates: Social representation in Brisbane newspaper media. Urban Studies. 54(6) 1519-1536.

http://journals.sagepub.com/doi/10.1177/0042098015624385

Raynor, K. Matthews, T. \& Mayere, S. (2017) Shaping urban consolidation debates: Social representation in Brisbane newspaper media. Urban Studies. 54(6) 1519-1536.

http://journals.sagepub.com/doi/10.1177/0042098015624385 


\section{Abstract}

Recent international trends towards urban consolidation, intended to reduce outward urban sprawl by concentrating growth within existing neighbourhoods, can cause contention in cities. Understanding how the mass media represents urban consolidation can lead to more informed and democratic planning practices. This paper employs Social Representations Theory to identify and understand representations of urban consolidation in newspaper media. The theory recognises that the media is a key purveyor of public discourse and can reflect, shape, or suppress ideas circulating in society. This novel approach has not previously been applied to understanding social representations of urban consolidation strategies in the mass media. The rapidly growing and changing city of Brisbane, Australia, is utilised as a case study. Brisbane is situated in South East Queensland, the fastest growing region in Australia, and is governed by regional and local planning policies that strongly support increased densities in existing urban areas. Findings from a quantitative textual analysis of 449 articles published in Brisbane newspapers between 2007 and 2014 reveal key clusters and classes of co-occurring words that represent dominant social representations apparent in the newspaper corpus. The paper provides two key conclusions. The first is that social representations occurring in mass media represent an important source of information about 'common sense' understandings and evaluations of urban consolidation debates. The second is that urban consolidation is represented as a multi-faceted issue, including interrelated themes of housing, sustainable population growth, investment strategies and the interplay between politics and planning.

Raynor, K. Matthews, T. \& Mayere, S. (2017) Shaping urban consolidation debates: Social representation in Brisbane newspaper media. Urban Studies. 54(6) 1519-1536. 


\section{Introduction}

Urban consolidation, which involves planned strategies to increase residential dwellings and populations in existing urban areas, is one of the most controversial and widely-adopted planning strategies of recent decades (Dodson and Gleeson, 2007). Planning strategies which promote increased urban densities can provoke staunch contestation from stakeholder groups, including existing residents, developers and local politicians. Commonly cited fears include diminished quality of life, neighbourhood character and property values once densification occurs (Ruming and Houston, 2013). Understanding how urban consolidation is represented by the mass media can identify key areas of contention and reveal unanticipated opportunities for compromise. This paper seeks to add to literature concerned with understanding the acceptability of higher density urban development. It specifically focuses on social representations of urban consolidation in newspaper media articles in the city of Brisbane, Australia.

Brisbane is a highly relevant case study area as it is currently undergoing a period of dramatic change in its urban form and housing provision as it moves towards greater proportions of medium and high density housing to support its growing population. This paper employs Social Representations Theory (SRT) to conceptually and empirically examine how the mass media constructs and portrays urban consolidation. SRT is derived from social psychology and has thus far rarely been applied in urban studies (Hubbard, 1996). Social representations influence how people evaluate, understand and behave in relation to specific issues (Oswald and Efréndira, 2013). Applied to an examination of urban consolidation, SRT can provide insights into how facets of the strategy can be represented and in turn

Raynor, K. Matthews, T. \& Mayere, S. (2017) Shaping urban consolidation debates: Social representation in Brisbane newspaper media. Urban Studies. 54(6) 1519-1536.

http://journals.sagepub.com/doi/10.1177/0042098015624385 
interpreted by stakeholders. This paper's use of SRT is complemented by the use of pragmatic textual analysis, a method which often provides a methodological basis for SRT studies.

This paper proceeds with a review of urban consolidation literature pertaining to recent Australian experiences and associated stakeholder perceptions. Next, the paper discusses key tenets of Social Representation Theory and demonstrates its relevance to examining stakeholder representations of urban consolidation. A description of the methods used to identify and analyse key social representations is then provided, followed by insights from a quantitative analysis of Brisbane newspaper articles. Findings are discussed relative to representations of housing styles, property marketing, growth management, local and state politics, transport options and urban character. The paper concludes that the newspaper media is a valuable source of information about the social representations that constitute the 'common sense' understandings of urban consolidation. These social representations are multi-faceted, drawing upon the interrelated themes of housing, sustainable population growth, investment strategies and the interplay between politics and planning.

\section{Perceptions of urban consolidation in literature}

Efforts to increase urban densities have gained traction internationally in recent years. All Australian capital cities are actively developing planning frameworks to deliver consolidated urban forms. These policies are advocated for their ability to reduce carbon emissions, promote social cohesion, collocate housing with high-value jobs and amenities in central business districts, reduce unnecessary consumption of land and avoid excessive public expenditure on infrastructure (Searle, 2007; Ruming et

Raynor, K. Matthews, T. \& Mayere, S. (2017) Shaping urban consolidation debates: Social representation in Brisbane newspaper media. Urban Studies. 54(6) 1519-1536.

http://journals.sagepub.com/doi/10.1177/0042098015624385 
al., 2011). Newton and Glackin (2014) outline five key contemporary challenges faced by Australian cities that provide rationales for urban consolidation. These are: rapid population growth in capital cities; the increasing gap between housing supply and demand; high cost of housing relative to income; disconnect between housing types and consumer demand; and the continued expansion of urban sprawl.

Urban consolidation provokes debate and challenge in Australia in terms of its ability and capacity to meet social, economic and environmental sustainability goals. 'Infrastructure capacity, land capacity, economic feasibility, density, loss of economic activity and market demand are cited as barriers to uptake of consolidation in the Australian experience (Searle, 2004). Other barriers include community opposition, a lack of suitable sites, fragmented land ownership, lower profit margins, high land, construction and labour costs and regulatory charges (Gillen, 2007). These factors result in a level of uncertainty that can discourage Australian developers from delivering densified developments even when supportive planning frameworks exist.

Negative stakeholder attitudes can present a challenge to the realisation of urban consolidation projects (Cook et al., 2013). A range of socio-political factors have been posited as drivers of this opposition. These include counter-productive planning processes that encourage ambit claims from developers aiming to achieve higher densities in court (Woodcock et al., 2011). They also include a lack of trust in the government (Gillen, 2007) and developer or planning-led discourses that portray higher density housing as a short-term housing options or unsuitable places to raise children (Fincher, 2007). These factors can individually or collectively shape the way stakeholders perceive high density urban forms and in turn constitute barriers to the successful implementation and uptake of urban consolidation.

Raynor, K. Matthews, T. \& Mayere, S. (2017) Shaping urban consolidation debates: Social representation in Brisbane newspaper media. Urban Studies. 54(6) 1519-1536.

http://journals.sagepub.com/doi/10.1177/0042098015624385 
Stakeholder perceptions of urban consolidation in Australia can be divided into three broad areas of interest: housing preferences; community opposition; and housing discourses.

\section{Housing preferences}

Research into the attitudes, attributes and experiences of residents of higher density developments identify 'empty nesters', 'young professionals' and 'consumer-citizens' as key Australian housing consumption groups (Baker, 2013). The small pool of research pertaining to residential satisfaction with higher density housing highlights the contextual nature of residential satisfaction. Residential satisfaction is often more significantly related to neighbourhood factors such as 'environmental quality, traffic and pollution, noise, lack of cohesion and community involvement, lack of services and limited choice of residence', rather than density per se (Buys and Miller, 2012: 4). Similarly, satisfaction with dwelling style is not dependent upon whether housing is attached or detached and house design can be perceived as more important than site design (Day, 2000).

There remains a widely-held assumption that the quarter-acre suburban block with a single detached dwelling is something that many Australians aspire to and believe necessary to achieve the 'Australian Dream' (Kellett, 2011). Summarising longitudinal research conducted over two decades, Wulff et al. (2004) report an overwhelming Australian preference for homeownership of detached dwellings. Reasons posited for this include 'association with affluence and success; perceptions of safety; privacy; a setting of space, nature and greenery; and ease of automobile use and parking' (Smith and Billig, 2012: 318). There is evidence this preference may be changing, as an Australian study found that $50 \%$ of respondents nearing retirement thought their backyard would become too large as they aged, creating a potential necessity for downsizing (Kellett, 2011). In addition, a marked mismatch exists in desired and 
available detached suburban housing in Australia (Kelly et al., 2011). A shift in preferences towards semi-detached housing and high density housing styles now appears prevalent in some demographic groups, particularly young singles with left-leaning political ideologies (Jenks, 2013; Lewis and Baldassare, 2010). This shift could signal increasing preferences for higher density housing emerging in other demographics also, especially if provided with improved proximity to employment, shopping and entertainment (Buys and Miller, 2012).

\section{Community opposition}

Community objection to urban consolidation is often due to local residents' perceptions of potentially negative impacts of consolidated urban forms, including loss of amenity, property values and neighbourhood character (Searle, 2010). Objection has been researched as a reaction to changes in neighbourhood character (Woodcock et al., 2011), disturbance of established power hierarchies (Huxley, 2002), threats to concepts of 'home' or 'place' (Cook et al., 2013) and the discourses of third party rights (Cook et al., 2012; Ellis, 2004).

Research has found that attitudes are complex and often based on level of trust in government, individual ideology and the extent to which citizens agree with the necessity of the proposed development (Tighe, 2010). Public opinion research has focused on how similar attitudes are formed, arguing that media framing, values and ideology and stereotypes are usually far more influential than information in shaping public opinion (Tighe, 2010). According to Fischer and Ayturk (2011), the public has little awareness of the impacts and implications of sprawl relative to consolidation. This lack of saliency increases the chances of people using cognitive shortcuts, such as stereotyping, rather than considered decision making to form opinions (Tighe, 2010). In reviewing multiple cases of objection to 
medium density housing in Melbourne, Alves (2006) concluded that differences in form, typology, context and style of developments had very little impact on the planning processes they evinced. Opposition appeared to be more related to a 'bigger, unarticulated threat or problem of which the specific development becomes symbolic' (Alves, 2006: 298). This unarticulated and non-specific threat applied across developments and represented a shared opinion held by the public that manifested itself in community opposition.

\section{Housing discourses}

The different values, political outlooks and priorities of key participants in housing density debates have been largely overlooked in Australia and beyond (Dodson and Gleeson, 2007). Research by Fincher (2007); Fincher (2004) identifies narratives used by built environment professionals such as planners, developers and architects to support conventional housing styles to suit 'acceptable' life stages. While single family detached dwellings continue to be associated with inward-looking, bounded and familyoriented home places, there is a pervasive discursive construction of high-rise developments being made for childless households more interested in lifestyle than family (Fincher, 2007).

Planning and development discourses on the appropriateness of high-rise development for families, wealthy households and 'empty nesters' has changed markedly in the decades since the 60s. High density housing is no longer as a strategy for housing the urban poor. Instead it is now perceived as an unhealthy environment for families and most appropriate as an exclusive housing option for the wealthy (Costello, 2005). Within this shifting context, the role of the media is identified as key in shaping perceptions and discourses relating to high density housing and urban consolidation (Fincher, 2004; Costello, 2005; Sivam et al., 2012).

Raynor, K. Matthews, T. \& Mayere, S. (2017) Shaping urban consolidation debates: Social representation in Brisbane newspaper media. Urban Studies. 54(6) 1519-1536. http://journals.sagepub.com/doi/10.1177/0042098015624385 
Interpreting common sense representations of urban consolidation using Social Representations Theory

Conceptual approaches derived from social constructionism can identify ways in which social life is mediated through modes of communication (Fopp, 2008). Attention is placed on 'specific series of representations, practices and performances through which meaning is produced, connected into networks and legitimised' (Gregory, 2000: 180). Social constructionist studies acknowledge that society and social policy are malleable and subject to power struggles as actors fight for the ability to shape the context of debates and define issues (Jacobs et al., 2003). In urban studies social constructionist research has most commonly been achieved through discourse analysis (Jacobs, 2006). While discourse analysis bears similarities to Social Representations Theory (SRT), such as a focus on language and a concern with cultural rather than individual meaning-making, there are fundamental differences between the two (Moscovici and Marková, 1998). SRT is a cognitive rather than discursive approach (Dickinson and Dickinson, 2006). Social representations emerge through informal communication and serve as mental constructs that allow individuals to understand the world. In contrast, discourse analysis suggests that representations are discursive constructs that people create in talk and text (Potter and Edwards, 1999). SRT is therefore a novel theoretical lens for this study and is grounded in an established lineage of social psychological methodological precedent.

Social Representations Theory is primarily concerned with the ways in which knowledge is built, used and accepted as 'common sense' (Oswald and Efréndira, 2013). 'Common sense' is understood in SRT as 'taken-for-granted' knowledge that is used by people to structure and inform their actions and

Raynor, K. Matthews, T. \& Mayere, S. (2017) Shaping urban consolidation debates: Social representation in Brisbane newspaper media. Urban Studies. 54(6) 1519-1536.

http://journals.sagepub.com/doi/10.1177/0042098015624385 
decisions. SRT acknowledges that knowledge is created through processes of collective meaning-making and social practices. These processes can play out over generations, along with the ability of individuals to generate, interpret and transform knowledge inter-subjectively (Oswald and Efréndira, 2013). Social representations are conceptualised as both processes and products. As processes, they generate meanings ascribed to social objects through communication and discourse. As products, they constitute shared structures of knowledge and symbols that influence how individuals and groups discuss, conceptualise and react to certain phenomena (Wagner et al., 1999). A social representation can be considered a relatively consensual view of a social phenomenon that is particular to specific social networks.

Two processes generate social representations: anchoring and objectification. These processes make the unfamiliar familiar and integrate novelty into a more understandable format (Wagner et al., 1999). They occur when an unfamiliar phenomenon that threatens the course of everyday practice of a group forces group members to adapt practices to create a valid and collectively accepted explanation. Anchoring involves naming and classifying novel encounters, ideas and things in order to furnish social groups with a basic understanding of an unfamiliar concept by linking them with more familiar phenomena (Wagner and Hayes, 2005). Objectification makes new ideas tangible and functions to saturate the unfamiliar with something easier to understand (Joffe, 2003). These processes are employed by people trying to represent new forms of information. Anchoring and objectification processes ensure core values and norms are stamped onto new events and drive mutations in common sense over time (Joffe, 2003).

Raynor, K. Matthews, T. \& Mayere, S. (2017) Shaping urban consolidation debates: Social representation in Brisbane newspaper media. Urban Studies. 54(6) 1519-1536. http://journals.sagepub.com/doi/10.1177/0042098015624385 
The theory is suited to media analysis as mass media is social in its production, expression and consumption. Underlying meanings can be prevalent in the products of the mass media, including newspaper articles. The use of SRT is pertinent to the study of how the media constructs societal and political issues, as it provides a theoretical framework for exploring how the media naturalises social thinking and generates collective cognition (Höijer, 2011). Social representations in the mass media can become the enmeshed narratives of social influence. Salient discourses in the media play an important role in the construction of realities because they provide the public with words to represent a new phenomenon, as well as frameworks with which to understand it (Joffe, 2003). An acknowledgement that stakeholder attitudes towards urban consolidation are shaped in part by the mass media provides a conceptual entry point for using SRT in this paper.

While SRT has rarely been applied in urban studies, it offers significant utility (Andriotis and Vaughan, 2003). Devine-Wright (2009: 430) asserts that 'research informed by social representations theory can investigate how proposed place changes are interpreted, evaluated and contested amongst individuals and between individuals and organizations, mindful of the unequal power relations between different actors.' Different social representations compete in their claims to privilege specific realities and so limit and exclude other realities (Howarth, 2006). SRT studies can be used to critically investigate the ways in which certain perspectives are privileged over others, whose voices are heard and which versions of reality are deemed appropriate. In this context, identifying stakeholder representations of urban consolidation can illustrate ways in which certain perspectives are naturalised in the interest of powerful groups.

Raynor, K. Matthews, T. \& Mayere, S. (2017) Shaping urban consolidation debates: Social representation in Brisbane newspaper media. Urban Studies. 54(6) 1519-1536. http://journals.sagepub.com/doi/10.1177/0042098015624385 


\section{Methodology}

\section{Case study selection}

The city of Brisbane is located in the South East Queensland (SEQ) region and is the state capital. The city has received very limited attention in urban consolidation literature to date. However, it provides a useful and relevant case study due to its use of urban consolidation as a response to its current and future population pressures. The Brisbane City Plan 2014 is the primary city-scale planning document in Brisbane. It regulates local planning and seeks to advance state and regional planning policies at the city level (Brisbane City Council, 2014). Provisions in the plan concentrate growth in key nodes while retaining 'Suburban Living Areas' in which low density residential forms will remain (Brisbane City Council, 2014). The Brisbane City Plan 2014 is formulated in accordance with the provisions set by the statutory South East Queensland Regional Plan 2009-2031, which guides growth and development in SEQ and outlines compact development as a key regional policy. Brisbane is unique as being the only capital city in Australia governed by a single local government. The city has historically developed as a decentralised low-density urban form (Gillen, 2006) without the tradition of higher density living in other major Australian cities like Sydney and Melbourne (Searle, 2010; Mees, 2009). Brisbane has a current population density of $1000 / \mathrm{km}^{2}$, which is low compared to Sydney at $2000 / \mathrm{km}^{2}$ or Melbourne at 1500/km² (Demographia, 2014).

\section{Methodological rationale and data collection strategy}

The methodology underpinning this paper is based on quantitative textual analyses of newspaper articles. This approach is strongly linked to the use of SRT and is designed to identify ways in which knowledge is built and used by people. Media analysis presents an opportunity to illustrate cultural 
contexts and to explore 'ideas that reside in structures outside of individual minds' (Joffe, 2003: 66). Media portrayals are an important indicator of political context and public discussion and debate. In addition, media analysis can result in a better understanding of the social and cultural considerations that may be over-looked by expert-led management of urban development and housing provision (Sochacka et al., 2011). While the ability of the media to substantially impact policy is contested, it has been posited that the media can shape, convey and legitimate a certain view of reality, which in turn influences policy debates, context and decisions (Moscovici, 1976). Many studies identify strong correlations between media agendas and public agendas, indicating that the media acts as a filter for information consumed and shaping force in the formation of attitudes developed (Tighe, 2010).

This data collection process informing this paper aimed to discover how urban consolidation was represented in three Brisbane newspapers between 2007 and 2014. The Courier Mail and the Sunday Mail, published online and in print by News Corp; and The Brisbane Times, published online by Fairfax Media were examined. The combined daily circulation of The Courier Mail and Brisbane Times is 742 065, supplemented by 927,000 Sunday Mail readers on the weekend. These newspapers constitute the bulk of newspaper media consumed by readers in Brisbane. While print newspapers have suffered declining readership rates and a lack of engagement with younger demographics in recent times, they have bolstered their influence through an online presence and remain an important source of local news (Zenor, 2012). Australian media platforms exhibit high levels of concentration with content sharing deals in place between newspapers, television and radio news (Brevini, 2015). For this reason, it is argued that analysis of newspaper coverage can yield a meaningful, if not fully representative, overview of representations of urban consolidation in Brisbane.

Raynor, K. Matthews, T. \& Mayere, S. (2017) Shaping urban consolidation debates: Social representation in Brisbane newspaper media. Urban Studies. 54(6) 1519-1536. http://journals.sagepub.com/doi/10.1177/0042098015624385 


\section{Data analysis}

The 449 articles gathered during data collection were analysed using pragmatic textual analysis. The technique was used to identify key representations within the newspaper articles. Pragmatic textual analysis is often used to identify the 'lexical worlds' or word clusters used to describe specific social phenomena. The technique identifies statistical similarities and differences of words in order to ascertain repetitive language patterns (Flick et al., 2015). This study used the software IRaMuTeq (a French acronym for ' $\mathrm{R}$ interface for Multidimensional Analysis of Texts and Questionnaires') to apply statistical analysis of word stem co-occurrence to highlight significant vocabulary, thereby characterising clusters related to urban consolidation. The software uses a classification method to determine the main distribution patterns of word clusters and classes within a text. It does this using standard statistical parameters and without reference to the meaning of the words, thereby removing the potential for researcher bias (Caillaud et al., 2012). The aim of this process is to find words that are commonly associated with each other in a publicly-consumed text to highlight how urban consolidation is collectively defined, evaluated and classified. These word associations can reveal instances of objectification and may be interpreted as anchoring categories that reflect the way certain representations of urban consolidation are shared at the expense of others.

\section{Examining social representations of urban consolidation in Brisbane}

This section of the paper employs SRT as a conceptual lens to examine stakeholders' 'common sense' understandings of urban consolidation as portrayed in Brisbane's three main newspapers. An analysis of the newspaper corpus using IRaMuTeq software revealed 3 distinct 'lexical worlds', otherwise known as word clusters: Housing and Investment; Planning and Politics; and Urban Impacts. The clusters broadly 
correspond to social representations apparent in the newspaper corpus over the 7-year period of analysis. The clusters each divided into two lexical classes, providing six lexical classes in total (see Figure 1).

\section{INSERT FIGURE 1 HERE}

The six classes derived from the three over-arching word clusters each generate a set of significant words. Table 1 summarises the most significant words in each class and presents a sample statement indicative of each class. The word clusters have fallen into intuitive patterns, collating words into identifiable themes despite the fact that IRAMUTEQ does not consider word meanings when grouping terms.

\section{INSERT TABLE 1 HERE}

Insights from cluster 1: Housing and Investment (39\%)

There are two distinct classes within this cluster. The first, 'Housing Affordability and Demand', focuses upon homes and households within the context of decreased housing affordability in Brisbane. Strong emphasis is placed upon housing market movements and the shortage of available housing. This class uses homeownership and investment as an anchoring device, privileging homeowners or aspiring homeowners whilst silencing renters. This is evidenced in the link between housing affordability and interest rates and purchase prices rather than rental costs. Renting is commonly depicted as an inferior alternative that is inflicted on those who can't afford to buy. This corresponds to a body of research that has already identified the role of media in legitimating homeownership (Jacobs et al., 2003). Housing

Raynor, K. Matthews, T. \& Mayere, S. (2017) Shaping urban consolidation debates: Social representation in Brisbane newspaper media. Urban Studies. 54(6) 1519-1536.

http://journals.sagepub.com/doi/10.1177/0042098015624385 
consumers are divided by generation, tenure and levels of affluence, with young professionals represented as more amenable to higher densities. This class is anchored in the concept of the 'climbing the property ladder' (Fincher, 2004), clearly delineating Gen Y, Gen X and Baby Boomer housing needs and attaching various housing types with appropriate life stages. This class is also concerned with the lives, families, aspirations and experiences of different age groups in different housing types. This is illustrated by the frequency of terms like 'kid,' 'dog,' 'dream' and 'renter.'

The second class, 'Marketing Higher Density', is mostly reflected in marketing articles promoting the desirability, features and finish of apartments and townhouses in Brisbane. Key attributes include number of bedrooms and bathrooms, balconies, popularity with investors and owner-occupiers, rental return, design elements and furnishing, waterfront views, inclusion of a pool and a lifestyle location. This class focuses on physical features and there is little reference to 'home,' 'children,' 'family' or 'living,' suggesting these are not elements often referenced when marketing higher density dwellings. This representation of high-rise housing as a 'lifestyle' choice runs through marketing and news articles and is a stark contrast to previous discourses that linked high density with deviancy and social disorder (Costello, 2005). The prevalence of terms such as 'views', 'lifestyle' and 'boutique' serve to anchor highrise housing in notions of prestigious and consumption-based living. This marginalises the needs of lower-income households, while normalizing the connection between apartment living and high-income households. The use of the label 'owner-occupier' and focus on rental yield and investors also serves to position this housing choice as an investment rather than a home. Within this class, efforts towards urban consolidation appear supported only as far as the strategy is perceived to meet the specific needs of particular market groups. Media discourses surrounding high density and high-rise living have traditionally coincided with changes in market share and the characteristics of new occupiers (Costello, 
2005). This discourse appears applicable to Brisbane, where high-rise dwellings have attracted much higher levels of renters than lower density alternatives (Randolph, 2006).

Insights from cluster 2: Planning and politics (32\%)

This cluster is divided broadly into local political decision-making and state and regional level planning priorities. The 'Local Political Decision-Making' class depicts higher density development as a political conflict with inherent contestations. It has a strong normative focus, referring to residents as voters and ratepayers and acknowledging perceived presence or absence of power and democracy in planning processes. This class has the most references to community members and perceived community perspectives. It is interesting to note that this class is anchored in political legitimacy and democracy rather than character, amenity, property prices, infrastructure provision or other factors often associated with local planning debates or within NIMBY literature (Dovey et al., 2009). It also places heavy focus on political leaders rather than community groups, potentially reflecting relative levels of perceived influence. It has strong themes of agency, power relations, obligations, responsibilities and interactions. The emphasis upon procedural fairness, as evidenced in the use of terms such as 'submission', 'vote', 'application', 'process', 'assess', 'decision' and 'objection', is particularly significant. These findings connect with studies undertaken in Sydney that found communities often object to a lack of legitimacy in the planning process, rather than planning outcomes (Ruming and Houston, 2013). This class includes references to local disputes and frequent conflicts between political parties on the controversial topic of higher density. Notions such as 'protecting' and 'preserving' are also apparent, thereby anchoring high density reporting in notions of fear or conflict.

Raynor, K. Matthews, T. \& Mayere, S. (2017) Shaping urban consolidation debates: Social representation in Brisbane newspaper media. Urban Studies. 54(6) 1519-1536. http://journals.sagepub.com/doi/10.1177/0042098015624385 
In contrast to the Local Political Decision-Making class, key words in the 'Managing Regional Population Growth' class include 'The South East Queensland Regional Plan 2009-2031', 'population', 'growth', 'management' and 'challenges'. This theme anchors urban consolidation by juxtaposing it with urban sprawl, representing higher density as a necessary solution to the ills of unbounded sprawl. It also employs the Los Angeles skyline as an objectification of poor urban form that urban consolidation seeks to avoid. Urban consolidation is presented as a necessity that existing residents must 'cope with' if new residents are to enjoy adequate access to housing and services. Quotations are primarily sourced from Federal and State politicians and there is a marked acceptance of the inevitability of growth. This finding supports the idea that growth is rarely questioned in the media (Molotch, 1976). The class focuses on planning for dramatic future growth and depicts higher density and population growth more as a challenge to be tackled. This is reflected in frequent references to the 'population growth issue' in the South East Queensland Regional Plan 2009-2031 (Queensland Department of Infrastructure and Planning, 2009). This finding is an example of how justifications for urban consolidation have transformed over time to suit pertinent urban issues. While early density policy in Australia was predominantly advanced as a solution to slums (Dodson and Gleeson, 2007), the rapid and prolonged population growth that typified the years leading to the Global Financial Crisis became the focal point for contemporary consolidation debates. Population growth was often depicted as a crisis by the Queensland government crisis in order to justify densification policy in Brisbane (Taylor et al., 2014). It is interesting to note that this discourse subsided significantly after 2008.

Insights from cluster 3: Urban impacts (29\%)

This cluster focuses on impacts and outcomes of urban consolidation. These include the development of urban villages, non-motorised travel and consumption experiences such as 'the café society'. There is a 
clear delineation between urban-form impacts and transport-related impacts. The 'Urban Precinct Character' class is laden with ideas related to the notion of mixed-use precincts. Higher density is generally portrayed as both positive and necessary to managing growth and demand on transport infrastructure. The class also identifies the connection between urban renewal discourses and density. This word cluster is almost entirely defined by council and state government quotations and is an example of the ability for certain powerful groups to shape debates and social representations of novel phenomena. It focuses on the creation of 'village'-style areas that combine residential, commercial and retail land uses to create vibrant urban hubs where people can 'live, work and play.' The social representation that links higher densities and vibrant, mixed-use hubs that allow people to 'live, work and play' is also echoed in the Brisbane City Plan (Brisbane City Council, 2014: Theme Two). The councilled nature of these precincts is apparent in typical text segments which focus on 'areas identified by the plan', 'council proposals' and new development slated to occur 'under neighbourhood plans'. The positive depiction of mixed-use precincts is an example of changing policy and media representations as increased density was achieved through the deregulation of subdivision laws in previous decades (Guhathakurta and Stimson, 2007).

Representations of positive connections between higher density and improved transport options are clear in the 'Transport' class. This class strongly supports greater provision of public transport. The predominant representation is that densified urban form can positively impact travel behavior. This is evidenced in statements such as, 'Distances between houses and everyday services means people are encouraged to drive' and 'European cities often place heavy emphasis on the suppression of car use through street design.... that promotes walking, cycling and public transport.' The objectification of the virtuous European city is often invoked as articles draw on similar notions of activated cafe precincts,

Raynor, K. Matthews, T. \& Mayere, S. (2017) Shaping urban consolidation debates: Social representation in Brisbane newspaper media. Urban Studies. 54(6) 1519-1536.

http://journals.sagepub.com/doi/10.1177/0042098015624385 
linked by high-quality public transport and pedestrian areas. This objectification is closely linked to the aforementioned 'Urban Precinct,' reflecting images supported planning priorities towards urban villages and mixed-use developments. These beliefs are reflected in the South East Queensland Regional Plan 2009-2031 which 'promotes compact settlement by consolidating growth in existing areas which are close to public transport, to encourage reduced car usage and help fight congestion' (Queensland Department of Infrastructure and Planning, 2009). Identifying this social representation as prevalent in Brisbane urban consolidation debates is significant as it has been posited that a positive connection between density and transit choices is vastly overstated in much research (Mees, 2009). This may be the case but it does not seem to influence media representations of urban consolidation as capable of producing predominately positive transport outcomes in Brisbane.

\section{Further insights}

A graphical illustration (see Figure 2) of word distribution across each of the six classes was also created using results from pragmatic textual analysis. The figure depicts the importance of individual words (demonstrated through word size), levels of connection between each class and the level of specificity for each class (demonstrated by distance from the centre). Each class is represented by a different colour. Common words in urban consolidation debates such as 'area', 'development', 'network', 'congestion' and 'service' occur frequently, as demonstrated by their proximity to the centre of the figure. This suggests they have become part of 'common sense' understandings of urban consolidation across each class identified in Brisbane. Conversely, other words feature more predominately in individual classes. These include 'eye-sore' (Urban Precinct Character), 'pedestrian' (Transport), 'boutique' (Property Market), 'ownership' (Housing Affordability and Demand), 'overpopulation' (Managing Population Growth) and 'democracy' (Local Political Decision-Making). 


\section{INSERT FIGURE 2 HERE}

A significant correlation between words connected to transport (road, car, walk) and urban precincts (residential, storey, character) appears in the figure. This further illustrates that a strong belief persists in Brisbane newspapers that urban consolidation has the capacity to improve transport outcomes. Social representations are supportive of the belief that increased densities can reduce car dependency, improve pedestrian experience and provide urban spaces focused on people. This representation persists despite opposing evidence provided by urban consolidation scholarship. For example, Dodson (2007) argues that consolidation policy has often been predicated on the overly-deterministic belief that manipulating densities can result in certain social, environmental and economic outcomes, while Mees (2009) has argued that public transport usage is more strongly correlated with transport policies than density. In the case of Brisbane, it may be that common sense beliefs about the correlation between urban consolidation and positive transport outcomes do not reflect contemporary research findings. In other words, empirical evidence may be at odds with social representations but this does not necessarily undermine stakeholders' perceptions of their validity.

In addition, the focus on mortgages, dwelling prices and affordability in the media belies the fact that over a third of occupied dwellings in Brisbane are rented (Australian Bureau of Statistics, 2011). Newspaper articles featured frequent references to housing affordability, linking average incomes with median house prices but with little consideration of the impact of rental housing. Despite evidence of severe and growing deficits in affordable rental housing in Australian markets (Wulff et al., 2011), this issue appears to lack saliency in the media. The social representation reflected in the newspapers has

Raynor, K. Matthews, T. \& Mayere, S. (2017) Shaping urban consolidation debates: Social representation in Brisbane newspaper media. Urban Studies. 54(6) 1519-1536.

http://journals.sagepub.com/doi/10.1177/0042098015624385 
parallels to previous research which identified the normalisation of homeownership in Australian media (Jacobs et al., 2003) and government policy (Jacobs, 2015).

\section{Conclusion}

Urban consolidation is a complex and controversial strategy. Representations of the strategy and factors conditioning its acceptability are important matters for urban studies. This paper adds to these discussions through its innovative application of Social Representations Theory, drawing on pragmatic textual analysis, to understand how the mass media represents urban consolidation in Brisbane. These approaches, which have so far received little attention in urban studies, were applied to gain a deeper understanding of how urban consolidation is constructed and portrayed in the media, thus shaping stakeholder representations. Using a highly relevant case study of Brisbane, Australia, this paper identified the dominant social representations apparent in Brisbane newspapers and discussed the implications of these representations. The quantitative textual analyses of 449 articles from the three newspapers reveal three main 'lexical worlds', otherwise referred to as word clusters: Housing and Investment; Planning and Politics; and Urban Impacts. The word clusters capture and group the dominant social representations associated with urban consolidation in Brisbane as reflected in newspaper media.

The three word clusters each divided into two classes, providing a total of six perceptual classes. Under the Housing and Investment cluster, the 'Housing Affordability and Demand' class reflects discussions about home ownership and housing affordability. Investment in high density development is represented as profitable for property investors while the experiences of renters are silenced. High 
density is not necessarily perceived as a housing preference for many market participants, especially those seeking to own family homes. The 'Marketing Higher Density' class focuses on the desirability of high-density living as a lifestyle choice for market groups, particularly those with high incomes and without dependent children. This representation reinforces a perception that high density housing is often seen more as an investment than a traditional home. Within the Planning and Politics cluster the 'Local Political Decision-Making' class represents the political conflict and the perceived lack of legitimacy of the planning process. It also reveals the potential for distrust and conflict that may exist between local citizens and decision-makers when urban consolidation strategies are sought. The 'Regional Population Growth' class presents a social representation of higher density residential development in Brisbane as a means to alleviate urban sprawl fueled by sustained population growth. Within the Urban Impacts cluster, the 'Urban Precinct Character' class highlights some positive beliefs associated with urban consolidation, like mixed-use 'village-style' urban precincts. Interestingly, this style of consolidated urbanism appears to be an ideal of Brisbane City Council, who are now seeking to deliver higher densities through neighbourhood plans rather than ad-hoc interventions. Finally, the 'Transport' class identifies positive perceived connections between high-density living, reduced car reliance and increased public transport options. The predominant discourse in this class posits a positive relationship between transport and urban consolidation, despite a lack of clear empirical evidence.

The use of Social Representation Theory in this paper allows the concept of urban consolidation to be understood in new terms. Specifically it can be understood as a complex idea that is expressed in various forms by mass media and understood and used in a variety of ways by people in everyday conversation. This is an innovative, timely and useful addition to urban studies literature as it provides a new conceptual lens for understanding a common, complex and contested planning strategy. The word 
clusters and classes examined in this paper suggest that urban consolidation is a multi-faceted issue. It touches on interrelated themes of housing, planning and politics and is integrally linked to notions such as sustainable population growth, democratic planning processes and investment strategies.

Understanding representations of urban consolidation is useful for built environment actors seeking to pursue consolidation strategies. It creates awareness that the mass media can strongly condition stakeholder attitudes around housing, planning and political issues related to urban consolidation strategies. Additionally, different representative classes can privilege different stakeholder perspectives. This knowledge is beneficial to urban scholars and practitioners seeking to delineate the boundaries of urban consolidation debates and strategies.

\section{References}

Alves T (2006) Managing Medium Density Housing Development: A Municipal Case Study. PhD Thesis, Swinburne University of Technology, Melbourne

Andriotis K and Vaughan R. (2003) Urban Residents' Attitudes toward tourism development: the case of Crete. Journal of Travel Research 42:(2) 172-185.

Australian Bureau of Statistics. (2011) Census Quick Stats - 2011. Available at: http://www.abs.gov.au/websitedbs/censushome.nsf/home/quickstats?opendocument\&navpos $=220$.

Baker T. (2013) Home-making in Higher Density Cities: Residential Experiences in Newcastle, Australia. Urban Policy and Research 31:(3) 265-279.

Brevini B. (2015) From Media Policy to 'Big' Media Policy: The Battle for Pluralism in Australia. In: Barnett S and Townend J (eds) Media Power and Plurality: From Hyperlocal to High-Level Policy New York: Palgrave Macmillan.

Brisbane City Council. (2014) Brisbane City Plan 2014. Brisbane: Brisbane City Council

Buys L and Miller E. (2012) Residential satisfaction in inner urban higher-density Brisbane, Australia : role of dwelling, neighbours and neighbourhood. Journal of Environmental Planning and Management 55:(3) 319-338.

Caillaud S, Kalampalikis N and Flick U. (2012) The social representations of the Bali climate conference in the French and German media. Journal of Community \& Applied Social Psychology 22:(4) 363378.

Cook N, Taylor E and Hurley J. (2013) At home with strategic planning: reconciling resident attachments to home with policies of residential densification. Australian Planner 50:(2) 130-137. 
Cook N, Taylor E, Hurley J, et al. (2012) Resident third party objections and appeals against planning applications: implications for higher density and social housing. Report, Melbourne

Costello L. (2005) From Prisons to Penthouses: The Changing Images of High-Rise Living in Melbourne. Housing Studies 20:(1) 49-62.

Day LL. (2000) Choosing a House: The Relationship between Dwelling Type, Perception of Privacy and Residential Satisfaction. Journal of Planning Education and Research 19:(3) 265-275.

Demographia (2014) Demographia World Urban Areas: 10TH ANNUAL EDITION. Report,

Devine-Wright P. (2009) Rethinking NIMBYism: The role of place attachment and place identity in explaining place-protective action. Journal of Community \& Applied Social Psychology 19:(6) 426441.

Dickinson JE and Dickinson JA. (2006) Local Transport and Social Representations: Challenging the Assumptions for Sustainable Tourism. Journal of Sustainable Tourism 14:(2) 192-208.

Dodson J and Gleeson B (2007) The use of density in Australian planning. In: State of Australian Cities (ed Hamnett S), Adelaide, 28-30 November, Australian Regions and Cities Network.

Dovey K, Woodcock I and Wood S. (2009) Understanding neighbourhood character: The case of Camberwell. Australian Planner 46:(3) 32-39.

Ellis G. (2004) Discourses of Objection: Towards an Understanding of Third-Party Rights in Planning. Environment and Planning A 36:(9) 1549-1570.

Fincher R. (2004) Gender and life course in the narratives of Melbourne's high-rise housing developers. Australian Geographical Studies 42:(3) 325-338.

Fincher R. (2007) Is high-rise housing innovative? Developers' contradictory narratives of high-rise housing in Melbourne. Urban Studies 44:(3) 631-649.

Fischer H and Ayturk G (2011) Residential Density (Liveable Communities) Market Perceptions Final Report. Report, Adelaide

Flick U, Foster J and Caillaud S. (2015) Researching Social Representations In: Sammut G, andreouli E, Gaskell G, et al. (eds) The Cambridge Book of Social Representations. Cambridge: Cambridge University Press, 64-82.

Fopp R. (2008) Social Constructionism and Housing Studies: A Critical Reflection. Urban Policy and Research 26:(2) 159-175.

Gillen M. (2006) The challenge of attaining a sustainable urban morphology for South East Queensland. Planning Practice \& Research 21:(3) 291-308.

Gillen M (2007) Analysing the Spatial and Market Ambiguities of Densification in Activity Centers: Case Study South East Queensland,. In: International Conference of Sustainable Urban Areas (ed Rotterdam, 25-28 June,

Gregory D. (2000) Discourse. In: Johnston RJ (ed) The dictionary of human geography. 4th ed. Oxford Blackwell.

Guhathakurta S and Stimson RJ. (2007) What is Driving the Growth of New "Sunbelt" Metropolises? Quality of Life and Urban Regimes in Greater Phoenix and Brisbane-South East Queensland Region. International Planning Studies 12:(2) 129-152.

Höijer B. (2011) Social Representations Theory: A New Theory for Media Research. Nordicom Review 32:(2) 3-16. 
Howarth C. (2006) A social representation is not a quiet thing: exploring the critical potential of social representations theory. The British journal of social psychology / the British Psychological Society 45:(Pt 1) 65-86.

Hubbard P. (1996) Urban Design and City Regeneration: Social Representations of Entrepreneurial Landscapes. Urban Studies 33:(8) 1441-1461.

Huxley M (2002) 'This suburb is of value to the whole of Melbourne': Save Our Suburbs and the struggle against inappropriate development. Report, Melbourne

Jacobs K. (2006) Discourse Analysis and its Utility for Urban Policy Research. Urban Policy and Research 24:(1) 39-52.

Jacobs K, Kemeny JIM and Manzi T. (2003) Power, Discursive Space and Institutional Practices in the Construction of Housing Problems. Housing Studies 18:(4) 429-446.

Jenks M. (2013) The Acceptability of Urban Intensification. In: Burton E, Jenks M and Williams K (eds) Achieving Sustainable Urban Form. Hoboken: Taylor and Francis, 242-251.

Joffe H. (2003) Risk: From perception to social representation. British Journal of Social Psychology 4255-73.

Kellett J. (2011) The Australian quarter acre block: The death of a dream? Town Planning Review 82:(3) 263-284.

Kelly J, Breadon P and Reichl J (2011) Getting the housing we want. Report, Grattan Institute, Melbourne Lewis PG and Baldassare M. (2010) The complexity of public attitudes toward compact development. Journal of the American Planning Association 76:(2) 219-237.

Mees P. (2009) How Dense Are We? Another Look at Urban Density and Transport Patterns in Australia, Canada and the USA. Road \& Transport Research: A Journal of Australian and New Zealand Research and Practice 18:(4) 58-67.

Molotch H. (1976) The City as a Growth Machine: Toward a Political Economy of Place. American Journal of Sociology 82:(2) 309-332.

Moscovici S. (1976) Social influence and social change, London: Academic Press.

Moscovici S and Marková I. (1998) Presenting Social Representations: A Conversation. Culture \& Psychology 4:(3) 371-410.

Newton P and Glackin S. (2014) Understanding Infill: Towards New Policy and Practice for Urban Regeneration in the Established Suburbs of Australia's Cities. Urban Policy and Research 32:(2) 123.

Oswald S and Efréndira S. (2013) The potential of social representations theory (SRT) for gender equitable research. Acta Colombiana de Psicología 63-70.

Potter J and Edwards D. (1999) Social Representations and Discursive Psychology: From Cognition to Action. Culture \& Psychology 5:(4) 447-458.

Queensland Department of Infrastructure and Planning. (2009) South East Queensland Regional Plan 2009-31, Southern Region Division: Brisbane

Randolph B. (2006) Delivering the compact city in Australia: current trends and future implications. Urban Policy and Research 24:(4) 473-490.

Ruming K and Houston D. (2013) Enacting planning borders: consolidation and resistance in Ku-ring-gai, Sydney. Australian Planner 50:(2) 123-129. 
Ruming K, Houston D and Amati M. (2011) Multiple Suburban Publics: Rethinking Community Opposition to Consolidation in Sydney. Geographical Research 50:(4) 421-435.

Searle G. (2004) Planning Discourses and Sydney's Recent Metropolitan Strategies. Urban Policy and Research 22:(4) 367-391.

Searle G (2007) Sydney's urban consolidation experience: Power, politics and community. Report, Brisbane

Searle G. (2010) Too concentrated? The planned distribution of residential density in SEQ. Australian Planner 47:(3) 135-141.

Sivam A, Karuppannan S and Davis M. (2012) Stakeholders' perception of residential density: a case study of Adelaide, Australia. Journal of Housing and the Built Environment 27:(4) 473-494.

Smith CA and Billig NS. (2012) Public Perceptions of Compact Suburbia in Progressive, Burgeoning Communities. Journal of Urban Design 17:(3) 313-335.

Sochacka N, Jolly L and Kavanagh L (2011) Understanding Rapid and Opportunistic Socio-technical Change in the Context of Urban Water Management. In: 2011 Georgia Water Resources Conference (ed Carroll GD), Georgia, April 11 - 13,

Taylor B, Wallington T, Heyenga S, et al. (2014) Urban Growth and Climate Adaptation in Australia: Divergent Discourses and Implications for Policy-making. Urban Studies 51:(1) 3-21.

Tighe JR. (2010) Public Opinion and Affordable Housing: A Review of the Literature. Journal of Planning Literature 25:(1) 3-17.

Wagner W, Duveen G, Farr R, et al. (1999) Theory and Method of Social Representations. Asian Journal of Social Psychology 2:(1) 95-125.

Wagner W and Hayes N. (2005) Everyday Discourse and Common Sense: the theory of social representations, New York: Palgrave Macmillan.

Woodcock I, Dovey K, Wollan S, et al. (2011) Speculation and Resistance: Constraints on Compact City Policy Implementation in Melbourne. Urban Policy and Research 29:(4) 343-362.

Wulff M, Healy E and Reynolds M. (2004) Why don't small households live in small dwellings? Disentangling a planning dilemma. People and Place 12:(1) 57-70.

Zenor J. (2012) Go to our website for more (of the same): Reassessing Federal policy towards newspapers mergers and cross emdia ownership and the harm to localism, diversity and the public inerest Available at: http://works.bepress.com/jason zenor/3/. 